\title{
Middle East Bulk Petroleum Terminal Remediation Strategy
}

\author{
R. William Johnston \\ PG, MBA Principal Geologist - Linebach Funkhouser, Inc. Louisville, KY
}

\section{Introduction}

A Bulk Petroleum Terminal in the Middle East (the Terminal) is located on the coast of the Red Sea. The site is bordered by a Government-Controlled building to the northwest, the Red Sea to the south and west, and vacant land to the southeast. A total of 20 large capacity above-ground storage tanks (ASTs) ranging in size between 75,000 barrels (bbls) (3,150,000 gallons) to 100,000 bbls $(4,2000,000$ gallons) are situated on the site, which include 12 ASTs containing diesel, four containing 95-octane gasoline, and four containing 91-octane gasoline. The Terminal went into operation in the 1980s and continues storing petroleum-based products through present day.

\section{Previous Studies}

Based on the results of previous environmental assessment work completed by environmental consultants over the timeframe of 2009-2011, historical operations on the property have resulted in the release of petroleum constituents to soil and groundwater. The predominant zone of affected soil was shown to be in the interpreted capillary fringe approximately 3 to 4 meters $(\mathrm{m})$ below surface grade. In addition to the detection of dissolved gasoline and diesel fuel constituents in groundwater, site assessment results showed the presence of a light, non-aqueous phase liquid (i.e. free-product) at the top of the water table in certain wells on the Terminal's property. Data from the past studies indicated that the most likely potential source area was situated beneath a former fueling station at the Terminal. Over the timeframe of 2009-2011, a total of 50 groundwater monitoring wells were installed at the Terminal by a Canadian-based environmental consulting company to evaluate the horizontal extent of contaminants in the subsurface. Supplemental to those 50 wells, six additional groundwater monitoring wells were installed on the adjacent Government-Controlled property to the northwest of the Terminal. Depth-to-groundwater measurements from the wells indicated that the water table was representative of an unconfined aquifer lying approximately four meters below ground level. Affected groundwater, including free-product, was shown to be migrating toward the west-northwest, in the direction of the Red Sea and (potentially) the Government-Controlled building.

\section{Proeject Contract/Purpose}

As a follow-up to the assessment studies previously conducted by the Canadian-based environmental consulting firm, the government's regulatory body retained a local Middle Eastern consulting company in 2012 to conduct interim action groundwater remediation activities at the site. In response to this request, a bid specification package was prepared by the local Middle Eastern consulting company for US-based companies to bid on the installation of the first groundwater remediation system to be installed within this Middle Eastern country. The purpose of the project was to install a US-constructed remediation system to eliminate and/or prevent further migration of free-phase and dissolved-phase contaminant plumes and vapor intrusion beneath the Government-Controlled building located northwest and downgradient of the Terminal's property line.

The local Middle Eastern consulting company awarded the 1.2 million dollar, 5-year contract to Linebach Funkhouser International, LLC (LFI) a US-based, 14-person environmental consulting firm with a single office in Louisville, Kentucky. The contract involved the installation of a pilot-scale remediation system that, in accordance with design criteria developed by the government's regulatory authority, was comprised of vacuum-enhanced, dual-phase extraction/air-sparge (VEDPE/AS) components.

\section{Installation/Operation/Maintenance (O\&M)}

LFI subcontracted Product Recovery Management, Inc. (PRM) based in Durham, North Carolina to construct and ship the remediation system to the site in the fall of 2013 . Installation of the system at the Terminal's site was completed in December of 2013 after overcoming numerous logistical challenges relative to shipping the first remediation system into the Middle Eastern country. The pilot-scale remediation system consisted of 15 recovery wells (RW-1 to RW-15) installed by LFI and a Middle-Eastern subcontracted drilling company. Each of the recovery wells were installed to depths of up to 9 meters and up to 14 meters apart based on calculated radius of influences. Google Earth was utilized to place the recovery wells in a two-line configuration adjacent to the Terminal's downgradient property boundary. The well placements were ground geo-coded on-site following the initial site visit based on the Terminal's infrastructure and site logistic 
constraints. A critical issue to the overall success of the project was to establish a mutual trust and understanding with the our client, the Middle Eastern consulting company (and their client) along with site personnel including the Terminal Foreman, Operations Foreman, Terminal Engineer and Maintenance Supervisor primarily in consideration of the language and cultural differences that existed between the US-based companies and the Middle Eastern-based companies.

The remediation system constructed by PRM included pumps, blowers, water-treatment equipment, a moisture separator, and an oil/water separator, all of which are situated inside a mobile enclosure (i.e. barge shipping crate) mounted on a concrete pad. During the initial site visit, the system's components were matched with the Terminal's on-site power supply sources to ensure compatibility with the remediation system. The VEDPE component of the system was designed to separate free-phase product from the groundwater before treating the remaining dissolved-phase using an air-stripper in conjunction with carbon filtration. The VEDPE component is currently being operated independently of the air sparge (AS) component in order to efficiently remove petroleum-impacted groundwater, particularly, the free-phase product on the water table. Once the freeproduct is effectively removed, the AS component of the system will be brought on-line to enhance the removal of volatile constituents in groundwater as well as the overlying affected soil. The system's control room included an HVAC system specifically designed to protect the system's sensitive electronics and motor drives from extreme heat temperatures encountered in a desert environment. The system was also equipped with internet access via a remote interfacing system to assist an on-site technician for troubleshooting from the U.S. project managers once they returned to the US.

The system commenced full-time operation near the end of 2013. Field measurements, observations, and system telemetry were used to make adjustments to the system following startup. Through the date of early spring, 2014, the system was powered by a $100 \mathrm{KW}$ diesel generator. The pilot system was temporarily shutdown for maintenance and to prepare for the installation of a permanent power line provided by the Terminal's power source to replace the generator. The conversion of the system from the diesel generator to the permanent power line was completed in the summer of 2014, and the system was re-started.

System maintenance work that consists of replacing the carbon in all four carbon vessels and cleaning the stainless-steel trays associated with the system are conducted on a routine basis. In addition, free-phase product and groundwater monitoring activities are being completed over a four year period in an effort to monitor the effectiveness of the system. This includes collecting quarterly sets of site-wide free-phase product and collecting water level measurements from all 56 monitoring wells using an oil/water interface probe. Following each gauging event, groundwater samples are collected from 22 wells that did not contain free-phase product. Groundwater sample collection activities are completed in general accordance with those referenced in the regulatory agency-approved Sampling and Analysis Plan (SAP) which was based on United States Environmental Protection Agency (USEPA) procedures. Low-flow sampling methodologies were implemented as described in USEPA's Low Flow (Minimal Drawdown) Ground-Water Sampling Procedures (April 1996) and ASTM Document 6771-02 (Standard Practice for Low-Flow Purging and Sampling Wells and Devices Used for Ground-Water Quality Investigations). Quarterly Groundwater Monitoring Reports are prepared in general accordance with the awarded contract to document the operation, maintenance and effectiveness of the VEDPE/AS groundwater remediation system. These reports along with $\mathrm{O} \& \mathrm{M}$ will continue for the duration of the contract which ends in 2017.

\section{Sampling/Monitoring}

The sampling procedures include the use of a variable-speed peristaltic pump and clean polyethylene tubing to complete well purging and sampling activities. As monitoring wells were being purged, a water level meter was used to track water level drawdown and a Yellow Springs Instruments, Inc. (YSI) 650 MDS multiparameter water quality instrument attached to an in-line flow-thru-cell was used to track water quality parameters. Intrinsic geochemical parameters are measured in the field including temperature, specific conductivity, hydrogen-ion concentration $[\mathrm{pH}]$, total dissolved solids, salinity, dissolved oxygen (DO), oxidation-reduction potential (ORP), turbidity, color, and odor. In general, prior to sample collection, purging was continued until intrinsic geochemical parameters were documented as being stable for the monitoring wells sampled, in accordance with the aforementioned USEPA and ASTM procedures. All monitoring wells (with the exception of six deep wells) had partially submerged well screens; therefore, groundwater samples were collected from the midpoint area between the top of the water column and the bottom of the well screen. Groundwater samples from the deep wells were collected from the midpoint area of the fully submerged well screen. A minimum of three equipment volumes of groundwater were purged prior to obtaining stabilization parameters, as required for minimal-drawdown (i.e. low-flow) sampling. Upon collection, groundwater samples were placed into laboratory-specified containers, labeled, and packaged in a cooler of wet ice. Samples were shipped under chain-of-custody to a Middle Eastern-based laboratory for analyses of the following constituents: 
- Volatile Organic Compounds (VOCs) by United States Environmental Protection Agency (USEPA) SW846 Method 8260B;

- Total Petroleum Hydrocarbons (TPHs) for Gasoline Range Organics (GROs) $\left(\mathrm{C}_{6}-\mathrm{C}_{9}\right.$ range) by USEPA SW846 Method 8260B;

- TPHs for Diesel Range Organics (DROs) $\left(\mathrm{C}_{10}-\mathrm{C}_{14}\right.$ range) by USEPA SW846 Method 8015;

- $\mathrm{TPH}$ for Oil Range Organics (OROs) $\left(\mathrm{C}_{15}-\mathrm{C}_{28}\right.$ and $\mathrm{C}_{29}-\mathrm{C}_{36}$ ranges) by USEPA SW846 Method 8015 ;

- Total Organic Carbon (TOC); and

- Natural attenuation indicators (Nitrate $\left[\mathrm{NO}_{3}\right]$, Sulfate $\left[\mathrm{SO}_{4}\right]$, Sulfide, Chloride, Alkalinity, dissolved and total Iron, and dissolved and total Manganese).

\section{Remediation System Effectiveness Monitoring}

In an effort to ensure that the remediation system had effectively removed chemical constituents before discharging the effluent water into the Red Sea, samples of untreated influent and treated effluent were collected from the system during each quarterly event. A sample was also collected from the air stripper (AS) pump.

\section{Results}

Results of performance monitoring activities associated with the pilot-scale remediation system have been favorable since the system startup in consideration of existing site conditions at the project's commencement.The site-wide distribution of free-phase product was monitored from system start up. In the fall of 2014, free-phase product was recorded in 33 of 56 monitoring wells, with a maximum thickness of 0.508 meters in one of the wells. None of the six deep monitoring wells contained free-phase product. A review of the data indicates that as the remediation system continues to operate, a greater volume of free-phase product is being pulled into the area of the 15 recovery wells. A certain degree of localized fluctuations in the measured thickness of free product is likely an artifact of tidal influence at the time the data was collected. Time-trend plots of free-phase product and water levels in select wells are monitored to determine how water table fluctuations are impacting free product thicknesses. Depth to groundwater at the site ranges from approximately 3.8 to 6.0 meters below ground level; water-table elevations generally ranged from approximately 0.6 meters to 1.1 meters relative to mean sea level (i.e. the National Geodetic Vertical Datum [NGVD] of 1929).

Due to the site's close proximity to the Red Sea, groundwater flow is tidally influenced. As such, tidal fluctuations can vary from 0.6 meters to 0.9 meters over the course of a single groundwater monitoring event. Therefore, interpretations of groundwater flow direction at any given time are speculative to a degree, as it is difficult to accurately plot potentiometric surface maps that truly represent the dynamic site conditions.

Dissolved fraction in the 22 monitoring wells absent of free product indicates that the petroleum-based constituents benzene, toluene, ethylbenzene, and total xylenes (BTEX) as well as methyl tert-butyl ether (MTBE) are the key constituents of concern at the site. System influent and effluent water samples are collected for comparison purposes. Constituents are detected in the influent sample, as expected. However, no constituents have been detected in effluent samples at concentrations that exceed their respective governmentestablished regulatory levels. Therefore, discharge via the Terminal's oil/water separator system and onto the Red Sea has been allowed.

\section{Summary and Conclusions}

The following summary and conclusions are based on results from remediation system monitoring, operation, and maintenance activities since system startup. In summary, the extent and thickness of free-phase product continues to fluctuate. This fluctuation appears to be an artifact of tidal influence. Along the downgradient property boundary of the Terminal, the localized reduction in product thickness appears to be a direct result of the groundwater remediation system. Since the system startup, the groundwater remediation system is effectively removing free-phase product along the downgradient property boundary. In addition, the groundwater remediation system is effectively treating the product/water mix that enters the system. The system will continue to operate until the termination of the contract period which ends in 2017.

\section{References}

[1]. American Society of Testing Materials. 2002. D 6771-02: Standard Practice for Low-Flow Purging and Sampling Wells and Devices Used for Ground-Water Quality Investigations.

[2]. https://www.google.com/earth/

[3]. Confidential Consultant, 2009a. Final Report-Subsurface Investigation Bulk Terminal. November 25, 2009.

[4]. Confidential Consultant, 2009b. Final Report-Risk Assessment Bulk Terminal. December 11, 2009.

[5]. Confidential Consultant, 2009c. Sampling Update - September 2009 Sampling Round, Bulk Terminal. December 16, 2009.

[6]. Confidential Consultant, 2010. Sampling Update - March 2010 Sampling Round, Bulk Terminal. October 4, 2010.

[7]. Confidential Consultant, 2011a. Final Report - Risk Assessment - Bulk Terminal - Offsite Investigation. December 2011. 
[8]. Confidential Consultant, 2011b. Final Report - Source Reduction Pilot Scale Program. December 2011.

[9]. Confidential Consultant, 2011c. Final Report - Subsurface Investigation Report - Bulk Terminal - Offsite Investigation. August 2011.

[10]. Linebach Funkhouser, Inc. 2013. Health, Safety, and Environmental Plan. March 19, 2013.

[11]. Environmental Projects, 2013. Sampling and Analysis Plan. December 4, 2013.

[12]. Environmental Projects, 2014. Remediation System Start-Up and Groundwater Monitoring Report - Fourth Quarter 2013. June 7, 2014.

[13]. Puls, R.W., and M.J. Barcelona. 1996. Low-Flow (Minimal Drawdown) Groundwater Sampling Procedures. USEPA/ORD EPA/540/S-95/504. Washington, DC: US Environmental Protection Agency.

[14]. $\quad$ Middle East. 2012. Engineering Procedure SAEP-391, Environmental Monitoring of Groundwater. August 2012.

[15]. Middle East. 2012. 2013 Middle East Tide Tables: Red Sea, Environmental Protection Department, Environmental Engineering Division, Marine Environmental Protection Unit.

[16]. Middle East. 2013. 2014 Middle East Tide Tables: Red Sea, Environmental Protection Department, Environmental Engineering Division, Marine Environmental Protection Unit.

[17]. United States Environmental Protection Agency. 1996. Low Flow (Minimal Drawdown) Ground Water Sampling Procedures. 